\title{
Cyanobacteria and microcystin contamination in untreated and treated drinking water in Ghana
}

\author{
Gloria Naa Dzama Addico, ${ }^{*}$ Jörg D. Hardege, ${ }^{2}$ Jiř́i Kohoutek, ${ }^{3}$ K.A.A. deGraft-Johnson, ${ }^{1}$ Pavel Babica ${ }^{3,4}$
}

${ }^{1}$ CSIR Water Research Institute, Achimota, Accra, Ghana; ${ }^{2}$ Biological Science Department, University of Hull, United Kingdom; ${ }^{3}$ RECETOX - Research Centre for Toxic Compounds in the Environment, Faculty of Science, Masaryk University, Brno, Czech Republic; ${ }^{4}$ Department of Experimental Phycology and Ecotoxicology, Institute of Botany, Czech Academy of Sciences, Brno, Czech Republic

*Corresponding author: naadzama443@hotmail.com

\begin{abstract}
Although cyanobacterial blooms and cyanotoxins represent a worldwide-occurring phenomenon, there are large differences among different countries in cyanotoxin-related human health risk assessment, management practices and policies. While national standards, guideline values and detailed regulatory frameworks for effective management of cyanotoxin risks have been implemented in many industrialized countries, the extent of cyanobacteria occurrence and cyanotoxin contamination in certain geographical regions is underreported and not very well understood. Such regions include major parts of tropical West and Central Africa, a region constisting of more than 25 countries occupying an area of 12 million $\mathrm{km}^{2}$, with a total population of 500 milion people. Only few studies focusing on cyanotoxin occurrence in this region have been published so far, and reports dealing specifically with cyanotoxin contamination in drinking water are extremely scarce. In this study, we report seasonal data on cyanobacteria and microcystin (MC) contamination in drinking water reservoirs and adjacent treatment plants located in Ghana, West Africa. During January-June 2005, concentrations of MCs were monitored in four treatment plants supplying drinking water to major metropolitan areas in Ghana: the treatment plants Barekese and Owabi, which serve Kumasi Metropolitan Area, and the plants Kpong and Weija, providing water for Accra-Tema Metropolitan Area. HPLC analyses showed that $65 \%$ samples of raw water at the intake of the treatment plants contained intracellular MCs (maximal detected concentration was $8.73 \mu \mathrm{g} \mathrm{L}^{-1}$ ), whereas dissolved toxins were detected in $33 \%$ of the samples. Significant reduction of cyanobacterial cell counts and MC concentrations was achieved during the entire monitoring period by the applied conventional water treatment methods (alum flocculation, sedimentation, rapid sand filtration and chlorination), and MC concentration in the final treated water never exceeded $1 \mu \mathrm{g} \mathrm{L}^{-1}$ (WHO guideline limit for MC-LR in drinking water). However, cyanobacterial cells (93-3,055 cell $\mathrm{mL}^{-1}$ ) were frequently found in the final treated water and intracellular MCs were detected in $17 \%$ of the samples (maximal concentration $0.61 \mu \mathrm{g} \mathrm{L}^{-1}$ ), while dissolved MCs were present in $14 \%$ of the final treated water samples (maximal concentration $0.81 \mu \mathrm{g}$ $\left.\mathrm{L}^{-1}\right)$. It indicates a borderline efficiency of the water treatment, thus MC concentrations in drinking water might exceed the WHO guideline limit if the treatment efficiency gets compromised. In addition, MC concentrations found in the raw water might represent significant human health risks for people living in areas with only a limited access to the treated or underground drinking water.
\end{abstract}

Key words: Cyanobacteria; cyanotoxins; drinking water treatment; microcystins; water blooms.

Received: October 2016. Accepted: May 2017.

\section{INTRODUCTION}

Concerns regarding the presence of cyanobacterial toxins (cyanotoxins) in drinking water and associated health effects have raised research and public health interest worldwide. Microcystins (MCs) are probably the most frequently found cyanotoxins which can be produced by various cyanobacterial genera including water bloom- and scum-forming planktonic cyanobacteria such as Dolichospermum (formerly Anabaena), Microcystis or Planktothrix (Manganelli et al., 2012). Cyanobacteria representing these genera have been previosly identified in Ghanaian water reservoirs along with other cyanobacterial species potentially producing MCs (Addico et al., 2006, 2009 , 2017). MCs are highly toxic for mammals with acute $\mathrm{LD}_{50}$ as low as 50-60 $\mu \mathrm{g} \mathrm{kg}^{-1}$, mouse, i.p. (Bláha et al., 2009; Van Apeldoorn et al., 2007). Their acute effetcs are primarily manifested in liver but MCs have been shown to induce gastrointestinal and renal damage or neurological symptoms as well (Manganelli et al., 2012). Chronic exposures to MCs have been linked to tumor promoting and carcinogenic effects which is based on laboratory animal and in vitro experiments (Svircev et al., 2010) and supported also by results of epidemiologic studies of human population consuming drinking water contaminated by these cyanotoxins (Fleming et al., 2002; Svircev et al., 2009, 2013, 2014; Ueno et al., 1996; Yu et al., 1995; Zhou et al., 2002). In fact, MCs have been classified as possible human carcinogen (class 2B) by the International Agency for Research on Cancer (Grosse et al., 
2006). In addition, other epidemiological studies associated exposures to toxic cyanobacterial blooms and MCs with chronic liver damage (Chen et al., 2009; Li et al., 2011; Zhang et al., 2015), and MCs were also implicated in neurotoxicity and neurodegenerative diseases (Feurstein et al., 2009, 2010). MCs are therefore regarded as human health hazard. Exposure of human beings to MCs can occur via different routes, such as recreational and sport activities in contaminated water, consumption of contaminated fish products or food supplements, and consumption of contaminated drinking water (Manganelli et al., 2012). The World Health Organization (WHO) set a provisional guideline limit of $1 \mu \mathrm{g} \mathrm{L}^{-1}$ of MC-LR in drinking water (WHO, 1998). Negative health outcomes resulting from drinking of water contaminated with cyanobacteria or cyanotoxins have been reported worldwide (Bláha et al., 2009; Van Apeldoorn et al., 2007; Wood, 2016). The only documented case of cyanobacteria-associated poisoning in Africa has been reported from Harare, Zimbabwe, where annual outbreaks of gastroenteritis among infants occurred after development of cyanobacteria blooms of Microcystis aeruginosa (KÜTZING) KÜTZING and Dolichospermum flos-aquae (BRESSON EX Bornet \& Flauhault) in Lake Chievero (Zilberg, 1966). However, there is also a documented case of threetime rise of gastroenteritis and 4.3-time increase of liver cancer incidence rate in Harare during the period 19902001 (Ndebele and Magadza, 2006). Although the extent to which this situation is linked to algal toxins is unclear, Johansson and Olsson (1998) reported that MC concentration in Lake Chievero was around $13.9 \mu \mathrm{g} \mathrm{L}^{-1}$ and $\mathrm{MC}$ was also detected in municipal tap water.

In the last decades, MC occurrence has been investigated in some African countries, with MCs reported from Northern Africa (Algeria, Egypt, Morocco, Tunisia), Eastern Africa (Ethiopia, Kenya, Mozambique, Tanzania, Uganda), Southern Africa (Botswana, Lesotho, South Africa) (Mowe et al., 2014; Harke et al., 2016; Ndlela et al., 2016). However, available data about cyanotoxin contamination are still very scarce for most African countries and being nearly absent for regions such as West and Central Africa (Mowe et al., 2014; Harke et al., 2016; Ndlela et al., 2016). These are two large geographical areas with 26 countries and nearly half a billion inhabitants, where Central Africa is represented by nine countries populated by approximately 155 mil people, and West Tropical Africa by 17 countries with a combined population of about 344 mil people (UNSD, 2014). Toxic or potentially toxic cyanobacterial blooms seem to occur frequently in this geographical area (Addico et al., 2006, 2009, 2017; Akin-Oriola et al., 2006; Berger et al., 2006; Haande et al., 2007; Mhlanga et al., 2006; Odokuma and Isirima, 2007). Nevertheless, MCs in this region have been so far reported from Nigeria (Chia et al., 2009a, 2009b; Chia and Kwaghe, 2015) and detected in water reservoirs Brimsu, Kwanyarko, Kpong and Weija in Ghana (Addico et al., 2006; Addico et al., 2017). Studies investigating cyanotoxins in drinking water and their removal during the water treatment have been even more scarce on the entire African continent, known to be conducted for example in Egypt (Mohamed and Carmichael, 2000), Algeria (Nasri et al., 2004), South Africa (Harding et al., 2009), and recently in two drinking reservoirs in Central Ghana (Addico et al., 2017).

In the present study, we investigated seasonal occurrence and removal of cyanobacteria and MCs in four treatment plants supplying the two major metropolitan areas in Ghana with drinking water. The study provides very rare but important information regarding the efficiency of drinking water treatment, concentrations and health risks of MCs in drinking water in the understudied geographical region of Central and West Tropical Africa.

\section{METHODS}

\section{Study area}

The Barekese Reservoir is a mesotrophic reservoir (Addico et al., 2009), which lies on latitude $6^{\circ} 49^{\prime} 50.2^{\prime \prime}$ $\mathrm{N}$ and longitude $1^{\circ} 43^{\prime} 21.8^{\prime \prime} \mathrm{W}$ (Fig. 1). This reservoir was formed in 1970, it has a surface area $6.4 \mathrm{~km}^{2}$ and maximal depth $15 \mathrm{~m}$ (Amuzu, 1975). It is located on the River Ofin, which flows through many farming areas before reaching the dam site (Kumasi et al., 2011).

The Owabi Reservoir, also mesotrophic (Addico et al., 2009), is located on latitude $6^{\circ} 44^{\prime} 35.7^{\prime \prime} \mathrm{N}$ and longitude $1^{\circ} 42^{\prime} 13.4^{\prime \prime} \mathrm{W}$ (Fig. 1). It was constructed in 1928 and upgraded in 1954. The reservoir has a surface area about $3.5 \mathrm{~km}^{2}$ and a mean depth $7 \mathrm{~m}$ (Akoto et al., 2014). The Owabi Reservoir is fed by seven rivers/streams, all of which flow through the densely populated Kumasi Metropolitan Area and the central business and industrial areas. The Owabi and Barekese Reservoirs are both situated in the Ashanti Region of Ghana and serving as major water supplies to Kumasi Metropolitan Area with a population over 2 mil people. The Owabi reservoir is designed to produce up to $20 \%$ of the total potable water requirement (Akoto et al., 2014), while the Barekese treatment plant is providing about $80 \%$ of the total piped drinking water to the Kumasi metropolis (Kumasi et al., 2011).

The Kpong Reservoir, described as mesotrophic (Addico et al., 2009), is located in the Eastern Region of Ghana on $6^{\circ} 07^{\prime} 1.3^{\prime \prime} \mathrm{N} 0^{\circ} 07^{\prime} 31.6^{\prime \prime} \mathrm{E}$ (Fig. 1). It was constructed in 1981 on the Volta River system mainly to provide hydroelectricity to supplement power generated from the Volta River dam. It has a total surface area of $38 \mathrm{~km}^{2}$, maximal depth of $15 \mathrm{~m}$ with a mean depth of $5 \mathrm{~m}$, and a mean annual flow $1183 \mathrm{~m}^{3} \mathrm{~s}^{-1}$ (Ansa-Asare and Ansong- 
Asante, 1998; Quarcoopome et al., 2011). The Kpong Reservoir apart from power generation is also used for drinking water production, irrigation, recreation and also well known for its fisheries, especially the tilapias.

The Weija Reservoir, a eutrophic reservoir (Addico et al., 2009), is situated in the Greater Accra Region of Ghana and lies on latitude $5^{\circ} 34^{\prime} 7.1^{\prime \prime} \mathrm{N}$ and $0^{\circ} 20^{\prime} 44.8^{\prime \prime}$ W (Fig. 1). It has a surface area of about $38 \mathrm{~km}^{2}$, a mean depth of $5 \mathrm{~m}$ and a mean annual flow of $54.2 \mathrm{~m}^{3} \mathrm{~s}^{-1}$ (AnsaAsare and Ansong-Asante, 1998, Asante et al., 2008). The Weija Reservoir was built in 1977 on the Densu River system. This river system is under intensive threat from heavy pollution mainly from domestic and agricultural wastes. Major crops include maize, cassava, pineapples, pawpaw, banana, sugar cane and vegetables. Fishing is also very intensive in the reservoir sometimes with the use of chemicals. The Kpong and Weija Reservoirs are the two main drinking water supplies serving the AccraTema Metropolitan Area with a population about $2.3 \mathrm{mil}$ people, with the Kpong treatment plant providing approximately $47 \%$ and the Weija plant about $53 \%$ of piped drinking water for the metropolis (Stoler et al., 2012).

\section{Drinking water treatment procedure}

The water treatment procedure in the studied treatment plants starts from the water intake. In most reservoirs, raw water was collected from depths between 5 to $7 \mathrm{~m}$ (Addico et al., 2006), with the exception of the Barekese plant, where the intake point is placed at the level $1.5-3 \mathrm{~m}$ from the surface (Amuzu, 1975). Raw water is sieved using a mesh to remove big objects like plant parts, twigs etc. This step is followed by flocculation using aluminium sulphate (alum) at a $100 \mathrm{mg} \mathrm{L}^{-1}$ dose, mixing and passing

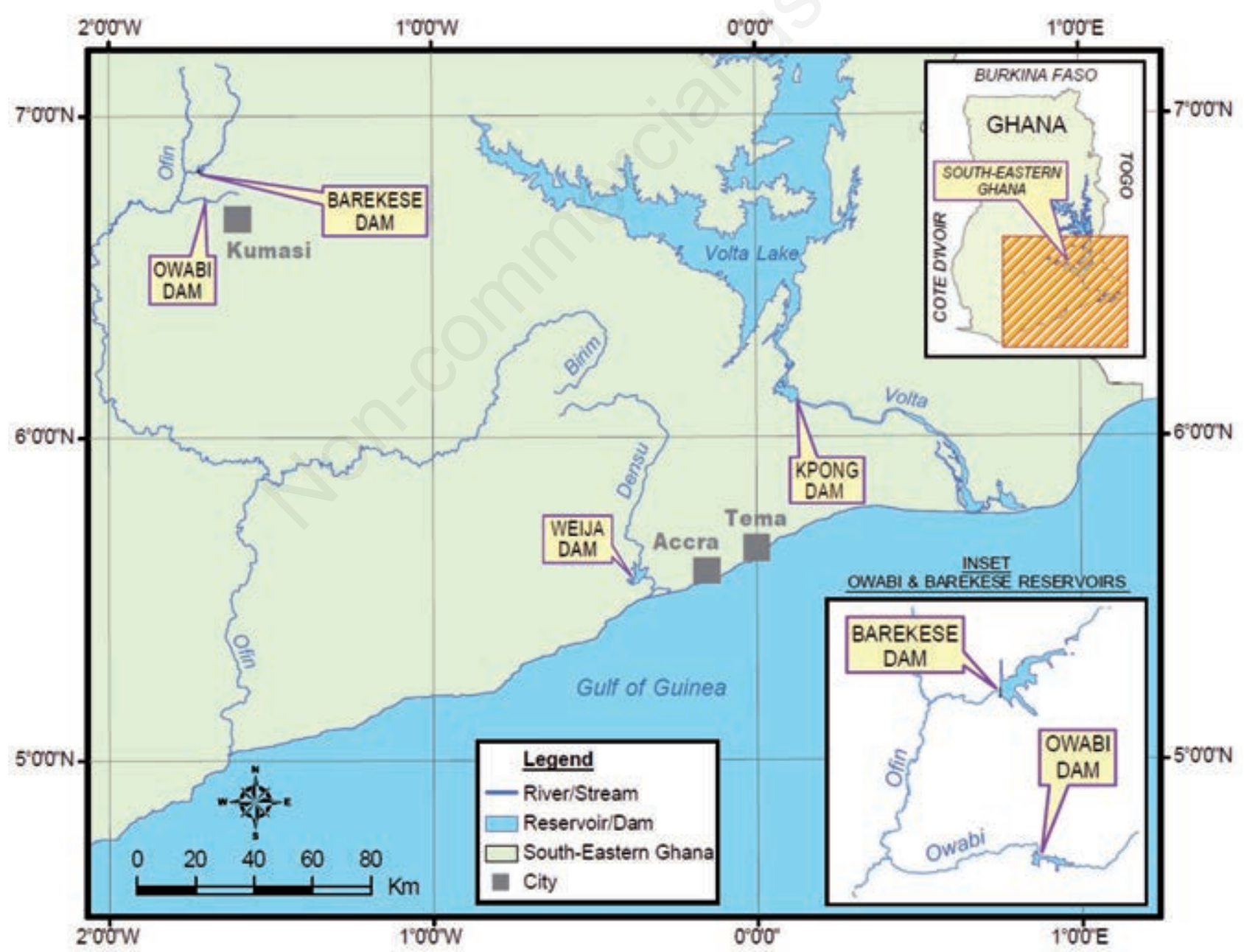

Fig. 1. Map of the reservoirs and treatment plants under the study. The Barekese and Owabi Reservoirs are located in the Ashanti Region of Ghana and supplying Kumasi Metropolitan Area with drinking water. The Kpong Reservoir is located in Eastern Region of Ghana, and the Weija Reservoir in Greater Accra Region, both reservoirs are providing drinking water for Accra-Tema Metropolitan Area. 
through baffles to maximise contact time. The flocs are allowed to settle out of the water in sedimentation tanks. The exception is represented by the Kpong Reservoir water treatment plant, where alum flocculation is not regularly applied during water treatment and water is prechlorinated before the filtration step. Filtration is then done by the rapid sand filtration method and the $\mathrm{pH}$ is adjusted to between 6.6 and 8.5 using lime. The final stage involves chlorination employing chlorine gas or calcium hypochlorite with a concentration of 0.5 to $1 \mathrm{mg} \mathrm{L}^{-1}$ of residual chlorine after a contact time of about $30 \mathrm{~min}$ (Fig. 2). All samples from the water intake to chlorination step were collected consecutively and within the same day. It is important to mention that during one time of sampling at the Owabi treatment plant, algaecide treatment with copper sulphate was simultaneously being applied in the reservoir.

\section{Sampling and cyanobacteria determination}

Samples for MC and cyanobacteria analysis were collected monthly from January-June 2005 from drinking water treatment plants at the Barekese and Owabi Reservoirs, and biweekly at the Weija and Kpong Reservoirs. Water samples $(1 \mathrm{~L})$ were collected into clean plastic

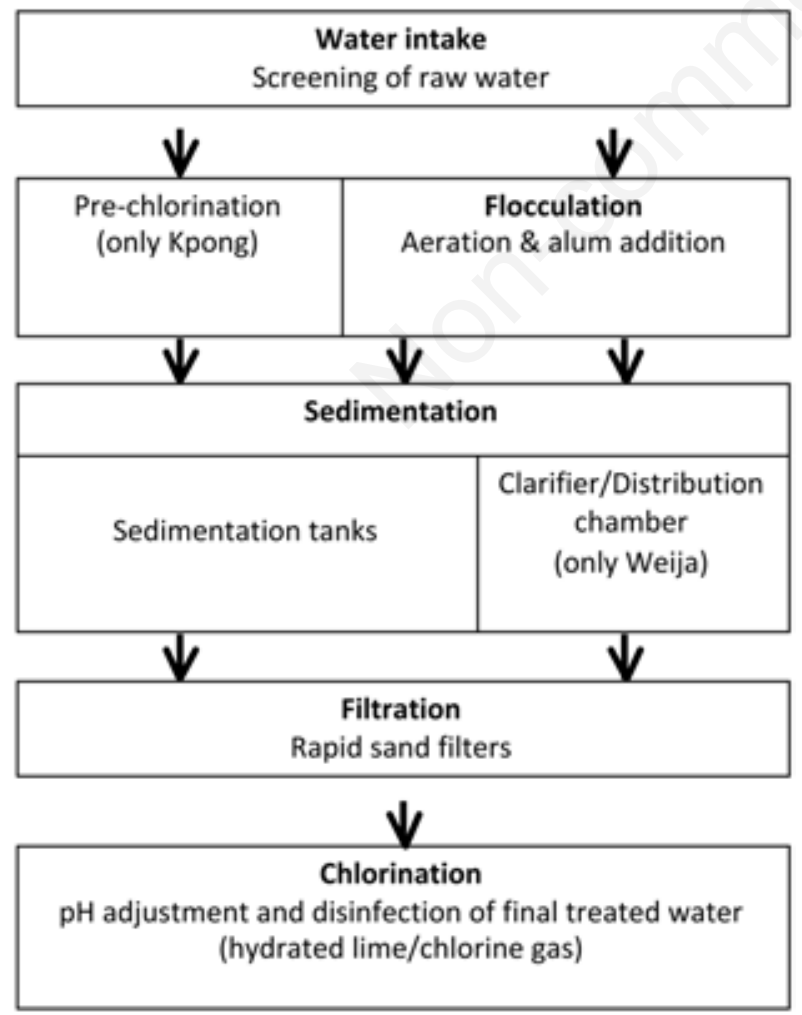

Fig. 2. Summary of drinking water treatment process employed in Ghanaian plants Barekese, Owabi, Kpong and Weija.
(PET) bottles from each treatment stage, namely: i) raw water at the intake; ii) flocculation (except the Kpong treatment plant); iii) sedimentation tanks or clarifiers; iv) filtered water; and v) final chlorinated water. A total number of 127 samples were analysed for intracellular MCs in the four reservoirs, whilst 59 samples were analysed for dissolved MCs. The lower number of samples analysed for dissolved MCs was due to financial constraints during the field work in Ghana and losses during the sample transport from Ghana to the United Kingdom.

Samples for microscopic determination of cyanobacterial species composition were collected from raw water and final treated water using plankton net $(25 \mu \mathrm{m})$ or by simply filling a bucket. Net samples were preserved for taxonomic work with formalin at the final concentration of $2 \%(\mathrm{v} / \mathrm{v})$, whilst water samples were preserved in Lugol's solution for quantitative microscopical analysis as described in Addico et al. $(2006,2009)$ using Olympus BX51 and BX60 microscopes equipped with objectives 10, 20, 40, 60 and 100X (Olympus). Briefly, the aliquots of the samples were transferred into counting chambers for analysis, where all colonies and filaments were counted as individuals. The average number of cells was determined for 20 individuals and cell concentration was calculated. Sub-samples for counting picocyanobacteria were filtered through a $0.2 \mu \mathrm{m}$ Nucleopore filter prestained with Irgalan black. Cells were stained with Dapi (4-diamidino-2-phenylindole dihydrochloride) and counted under the fluorescence (Excitation 330-385 nm, Emission 510-560 nm). About 300-400 picocyanobacterial cells were counted for each sample. All data on abundance were expressed as number of cells per $\mathrm{mL}$, including the cells inside colonies. Identification of cyanobacteria species was carried out at the Institute of Botany of the Czech Academy of Sciences, Trebon, Czech Republic under the supervision Prof. Jiří Komárek and using the recent taxonomical literature (Komárek and Anagnostidis, 1999, 2005).

\section{Extraction of cell-bound (intracellular) MCs}

Water samples $(1 \mathrm{~L})$ were filtered through preweighed GF/C filter (1.2 $\mu \mathrm{m}$ mesh, Whatman). The cells collected on the filters were frozen overnight and freeze-dried. Freeze-dried cells on filters were stored at $-20^{\circ} \mathrm{C}$ until extracted for HPLC analysis. Extraction of cell-bound (intracellular) toxins from freeze-dried cells was done as described by Harada et al. (1999). Cells were extracted with $20 \mathrm{~mL}$ of $75 \%$ aqueous methanol (Fastner et al., 1998) for 1 hour. This extraction step was repeated three times, the extracts from the individual steps were combined and then dried using a rotary evaporator. The concentrated extract was dissolved in $400 \mu \mathrm{L}$ methanol prior to HPLC analysis, filtered through $0.45 \mu \mathrm{m}$ nylon syringe filter (Millipore). 


\section{Extraction of dissolved (extracellular) MCs}

Filtrates of water samples $(1 \mathrm{~L})$ filtered through $\mathrm{GF} / \mathrm{C}$ filter (see above) were processed according to Harada et al. (1999). Briefly, filtrates were treated with sodium thiosulphate $\left(2 \mathrm{mg} \mathrm{L}^{-1}\right)$, acidified with trifluoroacetic acid (TFA, $0.1 \%, v / v)$ and concentrated using solid phase extraction by ODS cartridges (Supelclean LC-18, $3 \mathrm{~mL}$ Tube, Supelco). Cartridges were activated with $5 \mathrm{~mL}$ of methanol and rinsed with $5 \mathrm{~mL}$ of distilled water prior to the application of the sample. MCs were then eluted with $15 \mathrm{~mL}$ of $0.1 \%$ TFA in methanol, the eluate was evaporated to dryness by rotary vacuum evaporation $(45 \mathrm{C})$ and then redissolved in $400 \mu \mathrm{L}$ methanol in an ultrasonic bath.

\section{Identification and quantification of MCs}

MCs were identified and quantified using high performance liquid chromatography (HPLC Agilent 1100 series) system, coupled with a diode array detector (DAD). MCs were separated on a C-18 column Luna $150 \times 4.60$ $\mathrm{mm}, 5 \mu \mathrm{m}$ (Phenomenex) at $30^{\circ} \mathrm{C}$ using a flow rate of 1 $\mathrm{mL} \mathrm{min}^{-1}$. The binary gradient of the mobile phase consisted of (A) $\mathrm{H}_{2} \mathrm{O}+0.05 \%$ TFA and (B) acetonitrile $+0.05 \%$ TFA, with a linear increase from 30 to $70 \% \mathrm{~B}$ between 0-30 min. The injection volume was $20 \mu \mathrm{L}$. Chromatograms were recorded at $238 \mathrm{~nm}$. UV spectra (200 to $300 \mathrm{~nm}$ ) of all chromatographic peaks were carefully checked and compared to the spectra of MC standards: MC-LF, -LR, -LW, -RR and -LY (Alexis Biochemicals).
Peaks possessing the UV spectrum characteristic for MCs were quantified using a calibration curve $\left(\mathrm{n}=5, \mathrm{r}^{2=} 0.999\right)$ of the corresponding standard with the matching retention time. Unidentified peaks possessing the UV spectrum characteristic for MCs but not matching the retention time of the standards were quantified as MC-LR equivalents using the calibration curve of MC-LR (McElhiney and Lawton, 2005). The detection limit of the method (LOD) was $0.01 \mu \mathrm{g} \mathrm{L}^{-1}$ for the individual $\mathrm{MC}$ variant.

\section{RESULTS}

\section{Cyanobacteria removal}

In this study, we complemented previous data on cyanobacterial concentrations in the raw water (Addico et al., 2009) with a new data set on cyanobacterial cell counts in the final treated water, and also with MC analyses, in order to discuss relationships between MC occurrence, cyanobacterial diversity, and their removal during the drinking water treatment. As reported, all four reservoirs were dominated by cyanobacteria, which accounted for $70-90 \%$ of phytoplankton biomass (Addico et al., 2009). Detailed results of microscopical analyses of cyanobacterial species composition are summarized in Tabs. 1-4, the complete list of the identified species is provided in the Supplementary Tab. 1. Representatives of picocyanobacterial genera Cyanogranis, Aphanocapsa and Geitlerinema were among the most aboundant species

Tab. 1. Concentration of cyanobacterial cells $\left(\right.$ cell $\left.\mathrm{mL}^{-1}\right)$ in the water intake and in the final treated water at the Barekese drinking water treatment plant during the Jan-May 2005.

\begin{tabular}{|c|c|c|c|c|c|c|c|c|c|c|c|c|c|}
\hline \multirow[t]{2}{*}{ Barekese } & \multicolumn{2}{|c|}{ January } & \multicolumn{2}{|c|}{ February } & \multicolumn{2}{|c|}{ March } & \multicolumn{2}{|c|}{ April } & \multicolumn{2}{|c|}{ May } & \multicolumn{3}{|c|}{ Average } \\
\hline & Intake* & Final & Intake* & Final & Intake* & Final & Intake* & Final & Intake* & Final & Intake & Final & $\begin{array}{c}\text { Removal } \\
(\%)\end{array}$ \\
\hline Anabaena austro-africana & 0 & 0 & 35 & 0 & 140 & 0 & 89 & 0 & 926 & 0 & 238 & 0 & 100.0 \\
\hline Anabaena nygaardii & 7768 & 0 & 9010 & 54 & 11,509 & 10 & 4923 & 0 & 1922 & 0 & 7026 & 13 & 99.8 \\
\hline Chroococcus cronbergae & 756 & 0 & 467 & 0 & 899 & 0 & 1281 & 0 & 874 & 0 & 855 & 0 & 100.0 \\
\hline Cyanogranis ferruginea & 201,870 & 98 & 229,018 & 1143 & 191,002 & 475 & 48,594 & 45 & 125,000 & 87 & 159,097 & 370 & 99.8 \\
\hline Cylindrospermopsis raciborskii & 1007 & 11 & 4005 & 28 & 2086 & 12 & 4272 & 0 & 2760 & 0 & 2826 & 10 & 99.6 \\
\hline Merismopedia punctata & 2987 & 0 & 1998 & 0 & 1254 & 0 & 995 & 0 & 1075 & 0 & 1662 & 0 & 100.0 \\
\hline Merismopedia tenuissima & 7098 & 0 & 5998 & 0 & 5990 & 0 & 3709 & 0 & 2136 & 0 & 4986 & 0 & 100.0 \\
\hline Microcystis aeruginosa & 501 & 0 & 429 & 0 & 557 & 0 & 400 & 0 & 566 & 0 & 491 & 0 & 100.0 \\
\hline Oscillatoria princeps & 5783 & 0 & 6602 & 0 & 4998 & 0 & 5340 & 0 & 7251 & 0 & 5995 & 0 & 100.0 \\
\hline Planktolyngbya minor & 3056 & 0 & 2955 & 0 & 1565 & 0 & 1427 & 0 & 5073 & 0 & 2815 & 0 & 100.0 \\
\hline Planktothrix lacustris var. solitaria & 2008 & 3 & 3090 & 14 & 3163 & 8 & 5146 & 14 & 2895 & 25 & 3260 & 13 & 99.6 \\
\hline Planktothrix sp. & 98 & 33 & 801 & 99 & 2675 & 10 & 1226 & 26 & 3925 & 34 & 1745 & 40 & 97.7 \\
\hline Pseudanabaena recta & 6780 & 0 & 6675 & 10 & 3727 & 4 & 3888 & 7 & 925 & 2 & 4399 & 5 & 99.9 \\
\hline Radiocystis fernandoi & 0 & 0 & 96 & 0 & 230 & 0 & 0 & 0 & 431 & 0 & 151 & 0 & 100.0 \\
\hline Romeria elegans & 56 & 0 & 0 & 0 & 18 & 0 & 53 & 1 & 36 & 5 & 33 & 1 & 96.3 \\
\hline Total $\left(\right.$ cell $\left.\mathrm{mL}^{-1}\right)$ & 239,768 & 145 & 271,179 & 1,348 & 229,813 & 519 & 81,343 & 93 & 155,795 & 153 & 229,813 & 153 & \\
\hline Removal (\%) & & 99.9 & & 99.5 & & 99.8 & & 99.9 & & 99.9 & & 99.9 & \\
\hline
\end{tabular}

*Data adapted from Addico et al. (2009). 
within the cyanobacterial communities in the studied reservoirs (Tabs. 1-4). In the Barekese and Owabi Reservoirs, which are located in the same ecological zone in the Ashanti Region (Fig. 1), Cyanogranis ferruginea (F. WAWRIK) HINDAK ex Hindak accounted for the majority of cyanobacterial cells. C. ferruginea population in the raw water at the Barekese treatment plant ranged between $60-85 \%$ of total cyanobacteria cell counts (Tab. 1). This species was the most abundant in the treated water as well, accompanied also with Planktothrix agardhii (Gomont) K. Anagnostidis \& J. KomáreK, Planktothrix lacustris (KLEBAHN) I. UMEZAKI \& M. WATANABE, and eventually by Cylindrospermopsis raciborskii (WoloszYNSKA) SeEnayya \& Subba Raju, Pseudanabaena recta KomÁreK \& Cronberg, Anabaena nygaardii Cronberg \& KoMÁReK (Tab. 1). Concentrations of cyanobacterial cell in the final water from the Barekese Reservoir ranged between 93-1,348 cell $\mathrm{mL}^{-1}$.

In the Owabi treatment plant, $C$. ferruginea represented $95-97 \%$ of the total cyanobacteria cell counts (Tab. 2). In addition to C. ferruginea, cyanobacteria Aphanocapsa holstatica (Lemmermann) G. Cronberg \& Komárek, $P$. recta, and Leptolyngbya sp. were detected most frequently in the treated water from Owabi, with total cyanobacterial counts between 95-1099 cells mL $\mathrm{mL}^{-1}$ (Tab. 2).

Geitlerinema unigranulatum (C. AgARDH EX GOMONT) ANAGNOSTIDIS was the most abundant cyanobacterium in the Kpong Reservoir, representing $65-78 \%$ of total cyanobacterial cell counts in the raw water samples (Tab. 3). However, P. agardhii was in average the most abundant species found in the final water from the Kpong reservoir, followed by G. unigranulatum and C. raciborskii, while other species were detected in the treated water only occassionally. Total cyanobacterial cell counts in the final water were between $173-845$ cell $\mathrm{mL}^{-1}$ during the sampling period (Tab. 3).

Cyanobacterial community in the Weija Reservoir was the most diverse one (Tab. 4), when the most abundant cyanobacterial species Aphanocapsa nubilum KOMÁREK \& H.J. KLING accounted only for $18-26 \%$ of total cyanobacterial cell counts throughout six months of sampling, while being accompanied with Merismopedia tenuissima LemmermanN (14-19\%), Planktolyngbya minor (GEITLER \& RUTTNER) KOMÁREK \& CRONBERg (8$15 \%)$, P. recta (6-18\%) and others. The most abundant species in the treated water was Chroococcus cronbergae J. KoMÁREK \& E. NOVELO, which penetrated into the final stage throughout the study, along with $A$. nubilum, $M$. aeruginosa, A. nygardii, $P$. agardhii and C. raciborskii. The cyanobacterial cell counts in the final water from the Weija Reservoir were found to be between 369-3,055 cell $\mathrm{mL}^{-1}$ (Tab. 4). Overall, the drinking water treatment process eliminated $>97-99.9 \%$ of cyanobacterial cells, however, cyanobacteria were detected in $100 \%$ samples of treated water collected from all four treatment plants during the entire sampling period.

\section{MC removal}

Commonly occurring $\mathrm{MC}$ variants identified in the examined reservoirs were MC-LR, -LF, -RR and -YR. The highest diversity of $\mathrm{MC}$ variants was observed in the Weija Reservoir, where also two additional peaks possessing MClike UV absorption spectrum were identified. Out of the 26 samples of raw water, 17 samples $(65 \%)$ contained intracellular MCs (Fig. 3, Tab. 5). During the water treatment process, concentrations of both intracellular as well as extracellular toxins generally decreased with the treatment

Tab. 2. Concentration of cyanobacterial cells $\left(\right.$ cell $\left.\mathrm{mL}^{-1}\right)$ in the water intake and in the final treated water at the Owabi drinking water treatment plant during the Jan-May 2005.

\begin{tabular}{|c|c|c|c|c|c|c|c|c|c|c|c|c|c|}
\hline \multirow[t]{2}{*}{ Owabi } & \multicolumn{2}{|l|}{ January } & \multicolumn{2}{|c|}{ February } & \multicolumn{2}{|c|}{ March } & \multicolumn{2}{|c|}{ April } & \multicolumn{2}{|c|}{ May } & \multicolumn{3}{|c|}{ Average } \\
\hline & Intake* & Final & Intake* & Final & Intake* & Final & Intake* & Final & Intake* & Final & Intake & Final & $\begin{array}{c}\text { Removal } \\
(\%)\end{array}$ \\
\hline Anabaena nygaardii & 65 & 0 & 0 & 0 & 0 & 0 & 16 & 0 & 0 & 0 & 16 & 0 & 100.0 \\
\hline Aphanocapsa holsatica & 2092 & 76 & 1980 & 66 & 2541 & 97 & 1997 & 45 & 2672 & 76 & 2256 & 72 & 96.8 \\
\hline Chroococcus cronbergae & 67 & 0 & 0 & 0 & 10 & 25 & 0 & 0 & 0 & 0 & 15 & 5 & 67.5 \\
\hline Cyanogranis ferruginea & 225,317 & 34 & 220,001 & 47 & 165,002 & 901 & 157,005 & 37 & 278,430 & 98 & 209,151 & 223 & 99.9 \\
\hline Cylindrospermopsis raciborskii & 24 & 0 & 15 & 0 & 24 & 0 & 45 & 0 & 23 & 0 & 26 & 0 & 100.0 \\
\hline Leptolyngbya sp. & 946 & 0 & 882 & 27 & 98 & 0 & 107 & 13 & 905 & 9 & 588 & 10 & 98.3 \\
\hline Merismopedia tenuissima & 62 & 0 & 77 & 0 & 102 & 0 & 91 & 0 & 75 & 0 & 81 & 0 & 100.0 \\
\hline Planktolyngbya limnetica & 772 & 0 & 1372 & 0 & 1532 & 0 & 2109 & 0 & 815 & 0 & 1320 & 0 & 100.0 \\
\hline Planktolyngbya minor & 2008 & 0 & 1247 & 0 & 2349 & 0 & 2129 & 0 & 3761 & 0 & 2299 & 0 & 100.0 \\
\hline Pseudanabaena recta & 1465 & 56 & 2165 & 35 & 1645 & 76 & 1705 & 0 & 868 & 20 & 1570 & 37 & 97.6 \\
\hline Total $\left(\right.$ cell $\left.\mathrm{mL}^{-1}\right)$ & 232,818 & 166 & 227,739 & 175 & 173,303 & 1099 & 165,204 & 95 & 287,549 & 203 & 227,739 & 175 & \\
\hline Removal (\%) & & 99.9 & & 99.9 & & 99.4 & & 99.9 & & 99.9 & & 99.9 & \\
\hline
\end{tabular}

*Data adapted from Addico et al. (2009). 
step in all four individual treatment plants (Fig. 3). Statistically significant $(\mathrm{P}<0.05)$ correlation (Spearman's rank correlation coefficient $\rho$ ) between $\mathrm{MC}$ concentration and the order of treatment step was found: $\rho=0.996$ (Barekese), $\rho=0.861$ (Owabi), $\rho=0.987$ (Kpong) and $\rho=0.899$ (Weija) for intracellular toxins, and $\rho=1$ (Barekese), $\rho=0.911$
(Owabi), $\rho=0.965$ (Kpong) and $\rho=0.980$ (Weija) for dissolved toxins. However, increases in concentration of both intracellular and dissolved MC were observed in some cases after the flocculation/sedimentation steps of water treatment (Fig. 3 and Supplementary Figs. 1-4). Five samples of the treated water $(17 \%)$ contained intracellular or

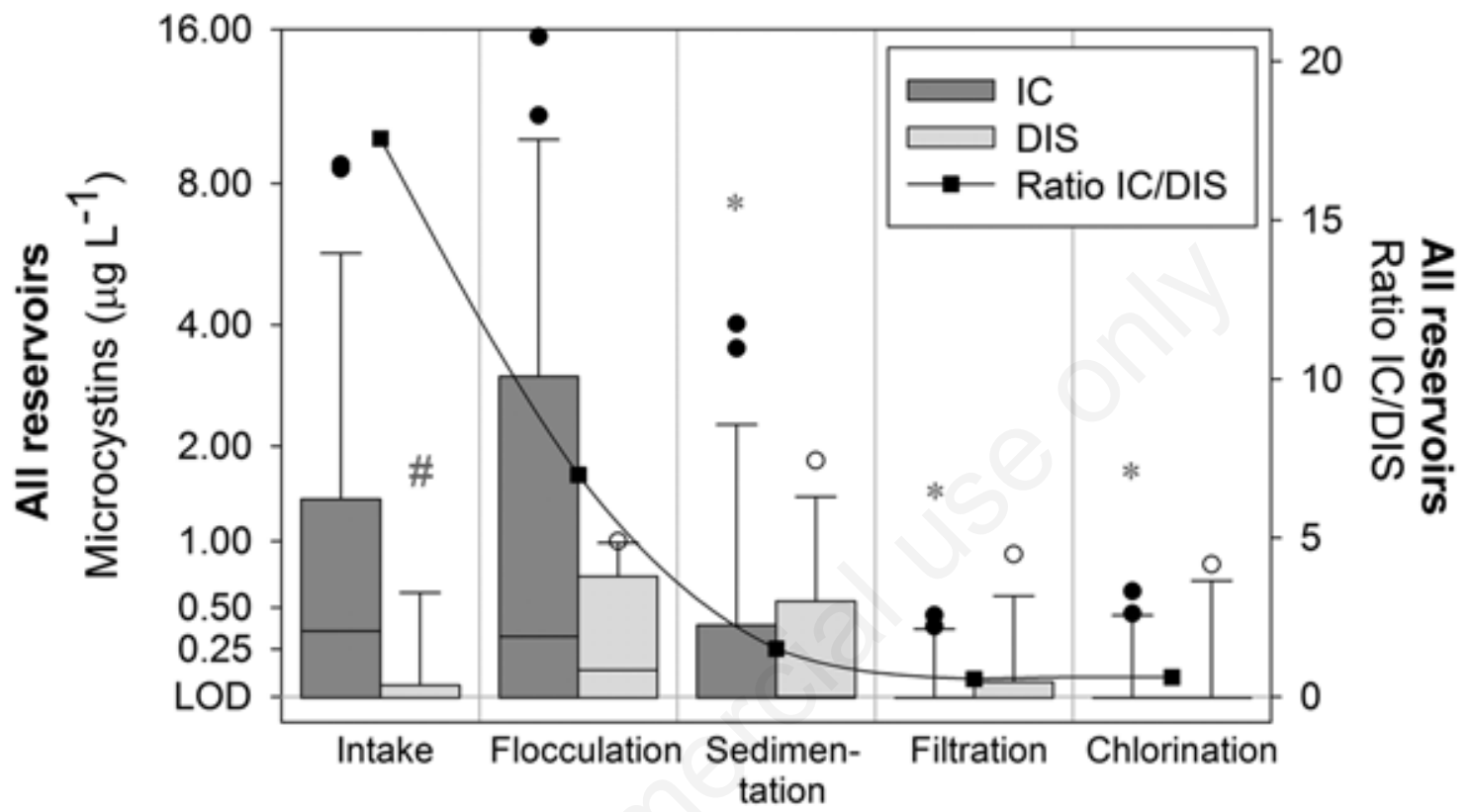

Fig. 3. Combined data on MC concentrations at different stages of four drinking water treatment plants in Ghana during Jan-Jun 2005. Boxes plot median values (middle lines), $25^{\text {th }}$ and $75^{\text {th }}$ percentils (boxes), $10^{\text {th }}$ and $90^{\text {th }}$ percentils (error bars) and outliers (circles). Ratio between median intracellular (IC) and dissolved (DIS) MC concentrations was calculated for different treatment steps and ploted as a line graph. Hash indicates significant difference between concentration of IC and DIS MC at the particular step of drinking water treatment $(\mathrm{P}<0.05$, Mann-Whitney test). Asterisks indicate significant difference between $\mathrm{MC}$ concentration in the water intake and a particular treatment step $\left(\mathrm{P}<0.05\right.$, Mann-Whitney test). Values below the method LOD $\left(0.01 \mu \mathrm{g} \mathrm{L}^{-1}\right)$ were susbstituted with LOD/2.

Tab. 3. Concentration of cyanobacterial cells $\left(\right.$ cell $\left.\mathrm{mL}^{-1}\right)$ in the water intake and in the final treated water at the Kpong drinking water treatment plant during the Jan-May 2005.

\begin{tabular}{|c|c|c|c|c|c|c|c|c|c|c|c|c|c|}
\hline \multirow[t]{2}{*}{ Kpong } & \multicolumn{2}{|l|}{ January } & \multicolumn{2}{|c|}{ February } & \multicolumn{2}{|c|}{ March } & \multicolumn{2}{|c|}{ April } & \multicolumn{2}{|c|}{ May } & \multicolumn{3}{|c|}{ Average } \\
\hline & Intake* & Final & Intake* & Final & Intake* & Final & Intake* & Final & Intake* & Final & Intake & Final & $\begin{array}{c}\text { Removal } \\
(\%)\end{array}$ \\
\hline Chroococcus cronbergae & 690 & 0 & 382 & 0 & 656 & 0 & 609 & 0 & 541 & 0 & 575 & 0 & 100.0 \\
\hline Coelomoron tropicale & 0 & 0 & 13 & 0 & 0 & 0 & 0 & 0 & 40 & 0 & 11 & 0 & 100.0 \\
\hline Cylindrospermopsis cuspis & 1226 & 0 & 1232 & 0 & 2401 & 0 & 1003 & 11 & 3980 & 0 & 1968 & 2 & 99.9 \\
\hline Cylindrospermopsis raciborskii & 2625 & 30 & 1806 & 39 & 2216 & 87 & 3873 & 35 & 2082 & 60 & 2520 & 50 & 98.0 \\
\hline Geitlerinema unigranulatum & 31,584 & 127 & 39,562 & 89 & 49,325 & 179 & 30,252 & 389 & 33,546 & 16 & 36854 & 160 & 99.6 \\
\hline Merismopedia punctata & 1204 & 0 & 924 & 0 & 840 & 0 & 550 & 0 & 1082 & 0 & 920 & 0 & 100.0 \\
\hline Merismopedia tenuissima & 2033 & 0 & 3693 & 0 & 2991 & 0 & 1563 & 0 & 3865 & 0 & 2829 & 0 & 100.0 \\
\hline Planktolyngbya minor & 55 & 0 & 61 & 0 & 90 & 0 & 61 & 0 & 1531 & 67 & 359 & 13 & 96.3 \\
\hline Planktothrix agardhii & 2475 & 65 & 4123 & 45 & 4070 & 293 & 2846 & 410 & 4352 & 41 & 3573 & 171 & 95.2 \\
\hline Pseudanabaena recta & 673 & 0 & 904 & 0 & 719 & 0 & 646 & 0 & 320 & 0 & 652 & 0 & 100.0 \\
\hline Total $\left(\right.$ cell $\left.\mathrm{mL}^{-1}\right)$ & 42,562 & 222 & 52,698 & 173 & 63,306 & 559 & 41,400 & 845 & 51,336 & 184 & 51,336 & 222 & \\
\hline Removal (\%) & & 99.5 & & 99.7 & & 99.1 & & 98.0 & & 99.6 & & 99.6 & \\
\hline
\end{tabular}

*Data adapted from Addico et al. (2009). 
particle-associated MCs (maximal detected concentration was $0.61 \mu \mathrm{g} \mathrm{L}^{-1}$ ), and two samples of the treated water (14\%) contained dissolved MCs at concentrations $0.57 \mu \mathrm{g}$ $\mathrm{L}^{-1}$ (Kpong) and $0.81 \mu \mathrm{g} \mathrm{L}-1$ (Weija) (Tab. 5). Concentrations of intracellular toxins significantly correlated with the concentrations of the cyanobacterial cells in the treated water $(\rho=0.561, P<0.01)$.

In the Barekese Reservoir, MCs were detected during two out of six sampling months (Tab. 5, Supplementary Fig. 1). In one instance (February $10^{\text {th }}$ ), intracellular MCs were found in the sedimentation step and then in the sample of treated water $\left(0.45 \mu \mathrm{g} \mathrm{L}^{-1}\right)$, while dissolved MCs were found in the flocculation stage (Supplementary Fig. 1). In April, intracellular MCs were detected in one sample of raw water at the concentration $0.46 \mu \mathrm{g} \mathrm{L}^{-1}$, which further increased in the flocculation stage, but then decreased below the detectable levels in the next treatment step (Tab. 5, Supplementary Fig. 1).
The Owabi Reservoir was found to be more contaminated with MCs. All raw water samples from the Owabi treatment plant contained intracellular MCs (Tab. 5, Supplementary Fig. 2). The highest detected concentration of intracellular MCs in the intake water from the Owabi Reservoir was $8.73 \mu \mathrm{g} \mathrm{L} \mathrm{L}^{-1}$, and intracellular toxins were detected also in the final water in one instance $(0.07 \mu \mathrm{g}$ $\mathrm{L}^{-1}$, March $\left.17^{\text {th }}\right)$. Dissolved MCs could be found in samples from all treatment stages of the Owabi treatment plant with the exception of the final stage (Tab. 5, Supplementary Fig. 2).

In the Kpong Reservoir, MCs were detected relatively less frequently. Intracellular toxins were found only in two out of seven samples of intake water (Tab. 5, Supplementary Fig. 3). However, the Kpong drinking water treatment plant, which does not have a flocculation stage, had two out of eight samples contaminated with intracellular MCs at the final chlorination stage $\left(0.13\right.$ and $0.46 \mu \mathrm{g} \mathrm{L}^{-1}$, March

Tab. 4. Concentration of cyanobacterial cells $\left(\right.$ cell $\left.\mathrm{mL}^{-1}\right)$ in the water intake and in the final treated water at the Weija drinking water treatment plant during the Jan-May 2005.

\begin{tabular}{|c|c|c|c|c|c|c|c|c|c|c|c|c|c|}
\hline \multirow[t]{2}{*}{ WeijaJanuary } & \multirow[b]{2}{*}{ Intake* } & \multicolumn{2}{|c|}{ February } & \multicolumn{2}{|c|}{ March } & \multicolumn{2}{|c|}{ April } & \multicolumn{2}{|c|}{ May } & \multicolumn{3}{|c|}{ Average } & \multirow[b]{2}{*}{$\begin{array}{c}\text { Removal } \\
(\%)\end{array}$} \\
\hline & & Final & Intake* & Final & Intake* & Final & Intake* & Final & Intake* & Final & Intake & Final & \\
\hline Anabaena austro-africana & 398 & 0 & 330 & 0 & 1,075 & 0 & 961 & 0 & 2807 & 0 & 1,114 & 0 & 100.0 \\
\hline Anabaena nygaardii & 2104 & 21 & 7080 & 475 & 5173 & 67 & 6485 & 35 & 11,297 & 15 & 6428 & 123 & 98.1 \\
\hline Anabaenopsis ambigua & 177 & 0 & 763 & 0 & 738 & 0 & 792 & 0 & 45 & 0 & 503 & 0 & 100.0 \\
\hline Anabaenopsis tanganyikae & 34 & 0 & 109 & 69 & 60 & 0 & 879 & 64 & 557 & 0 & 328 & 27 & 91.9 \\
\hline Aphanocapsa holsatica & 6302 & 25 & 2677 & 0 & 821 & 0 & 2151 & 0 & 6350 & 0 & 3660 & 5 & 99.9 \\
\hline Aphanocapsa nubilum & 24,567 & 12 & 20,538 & 883 & 20,832 & 80 & 26,883 & 42 & 19,511 & 67 & 22,466 & 217 & 99.0 \\
\hline Chroococcus cronbergae & 3141 & 515 & 5398 & 515 & 5284 & 962 & 5989 & 483 & 4586 & 224 & 4880 & 540 & 88.9 \\
\hline Coelomoron tropicale & 52 & 0 & 20 & 0 & 0 & 0 & 0 & 0 & 0 & 0 & 14 & 0 & 100.0 \\
\hline Cyanogranis ferruginea & 0 & 0 & 80 & 0 & 1208 & 0 & 903 & 0 & 1773 & 0 & 793 & 0 & 100.0 \\
\hline Cylindrospermopsis cuspis & 10 & 23 & 12 & 14 & 96 & 0 & 76 & 0 & 87 & 0 & 56 & 7 & 86.8 \\
\hline Cylindrospermopsis raciborskii & 1284 & 17 & 5148 & 97 & 4565 & 41 & 5051 & 25 & 4112 & 12 & 4032 & 38 & 99.0 \\
\hline Geitlerinema unigranulatum & 8 & 0 & 6 & 0 & 0 & 0 & 0 & 0 & 9 & 0 & 5 & 0 & 100.0 \\
\hline Lyngbya sp. & 6 & 0 & 0 & 0 & 5 & 0 & 6 & 0 & 12 & 0 & 6 & 0 & 100.0 \\
\hline Merismopedia punctata & 1414 & 0 & 627 & 0 & 263 & 0 & 3006 & 0 & 1461 & 0 & 1354 & 0 & 100.0 \\
\hline Merismopedia tenuissima & 20,859 & 48 & 20,907 & 34 & 17,794 & 0 & 15,059 & 5 & 12,916 & 0 & 17,507 & 17 & 99.9 \\
\hline Microcystis aeruginosa & 692 & 53 & 1782 & 744 & 2958 & 66 & 3051 & 47 & 2183 & 33 & 2133 & 189 & 91.2 \\
\hline Microcystis viridis & 0 & 0 & 0 & 0 & 0 & 0 & 0 & 0 & 493 & 0 & 99 & 0 & 100.0 \\
\hline Microcystis wesenbergii & 250 & 0 & 0 & 0 & 562 & 0 & 0 & 0 & 318 & 0 & 226 & 0 & 100.0 \\
\hline Planktolyngbya circumcreta & 162 & 0 & 75 & 0 & 416 & 47 & 439 & 0 & 219 & 0 & 262 & 9 & 96.4 \\
\hline Planktolyngbya limnetica & 3645 & 0 & 2774 & 0 & 5060 & 0 & 1843 & 0 & 2220 & 0 & 3108 & 0 & 100.0 \\
\hline Planktolyngbya minor & 13,843 & 0 & 16,883 & 0 & 12,610 & 0 & 11,736 & 0 & 7069 & 0 & 12,428 & 0 & 100.0 \\
\hline Planktothrix agardhii & 2395 & 11 & 2903 & 224 & 1311 & 37 & 2181 & 66 & 1757 & 18 & 2109 & 71 & 96.6 \\
\hline Planktothrix lacustris var. solitaria & 8723 & 0 & 6873 & 0 & 5299 & 0 & 2443 & 0 & 6130 & 0 & 5893 & 0 & 100.0 \\
\hline Pseudanabaena recta & 13,446 & 0 & 15,838 & 0 & 18,835 & 0 & 9624 & 0 & 5058 & 0 & 12,560 & 0 & 100.0 \\
\hline Radiocystis fernandoi & 3992 & 0 & 3395 & 0 & 2516 & 0 & 3089 & 0 & 1330 & 0 & 2864 & 0 & 100.0 \\
\hline Romeria elegans & 0 & 0 & 20 & 0 & 8 & 0 & 1 & 0 & 10 & 0 & 8 & 0 & 100.0 \\
\hline Total (cell mL) & 107,500 & 725 & 114,231 & 3055 & 107,485 & 1300 & 102,643 & 767 & 92,304 & 369 & 107,485 & 767 & \\
\hline Removal (\%) & & 99.3 & & 97.3 & & 98.8 & & 99.3 & & 99.6 & & 99.3 & \\
\hline
\end{tabular}

*Data adapted from Addico et al. (2009). 


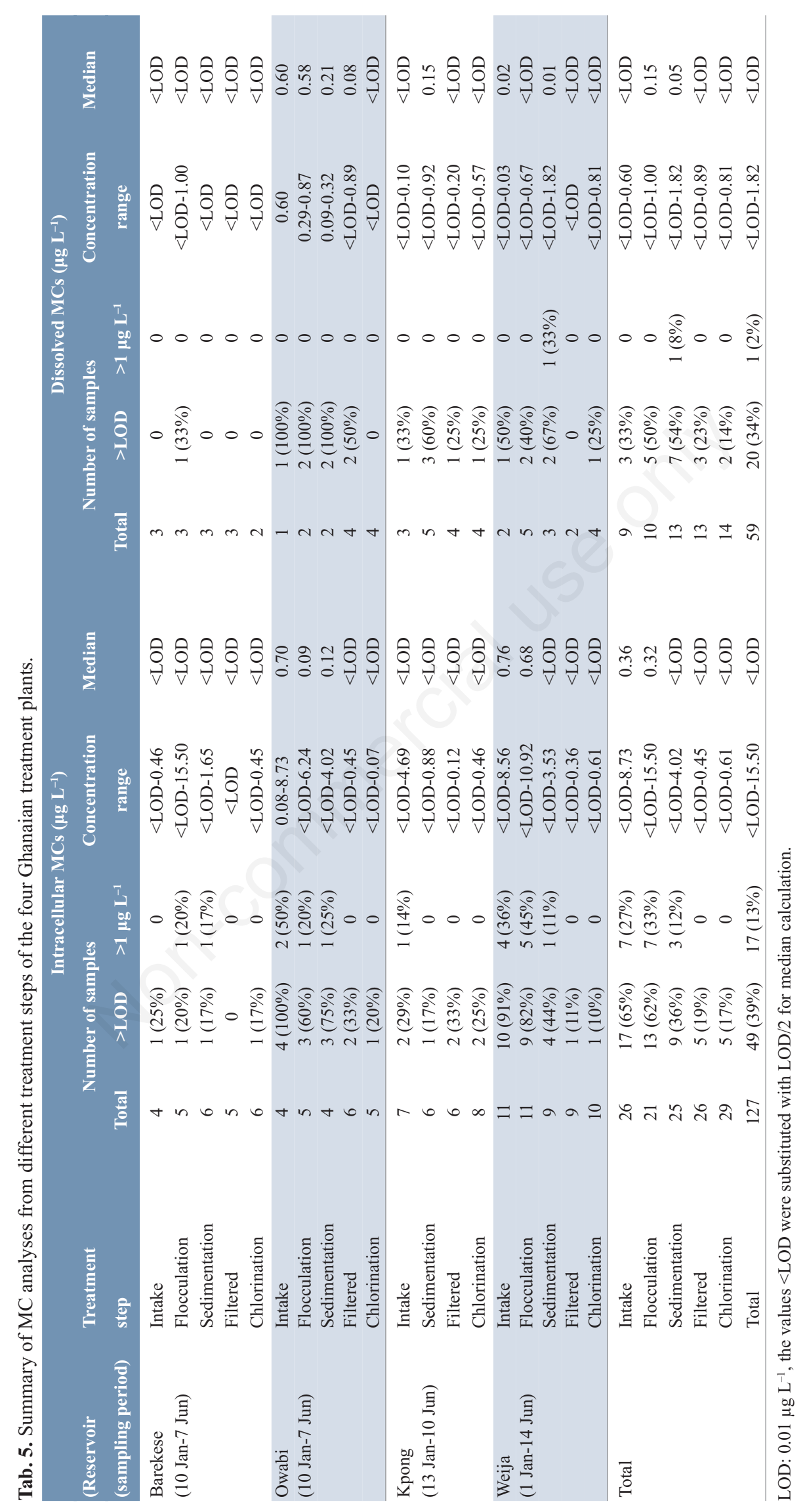


$10^{\text {th }}$ and April $8^{\text {th }}$ ). Concentrations of dissolved MCs showed a remarkable trend on March $24^{\text {th }}$, when increased from $0.1 \mu \mathrm{g} \mathrm{L}^{-1}$ at the water intake to $0.57 \mu \mathrm{g} \mathrm{L}^{-1}$ at the final drinking water treatment stage (Supplementary Fig. 3).

The raw water from the Weija Reservoir was more heavily contaminated with MCs, which were found in the particle fraction in ten out of 11 samples at the water intake, with the highest detected concentration $8.56 \mu \mathrm{g} \mathrm{L}^{-1}$ (Tab. 5, Supplementary Fig. 4). Concentrations of intracellular MCs in the Weija Reservoir often increased at the flocculation step and gradually decreased as the treatment proceeded to the final water stage (Supplementary Fig. 4). One sample of the final drinking water contained $0.61 \mu \mathrm{g}$ $\mathrm{L}^{-1}$ of intracellular MCs (February ${ }^{\text {th }}$ ). The highest concentration of dissolved MCs in the treated water $(0.81 \mu \mathrm{g}$ $\mathrm{L}^{-1}$ ) was observed on January $24^{\text {th }}$, and resulted from an increase in the concentrations of dissolved toxins during the treatment process (Supplementary Fig. 4).

\section{DISCUSSION}

As recently reviewed by Bernard et al. (2017), ten cyanobacterial genera detected in our study (Tabs. 1-4, Supplementary Tab. 1) have been previously associated with MC production: Anabaena/Dolichospermum, Anabaenopsis, Aphanocapsa, Geitlerinema, Leptolyngbya, Merismopedia, Microcystis, Oscillatoria/Planktothrix, Pseudanabaena and Radiocystis. Indeed, we frequently detected intracellular MCs in the samples of raw water collected from four Ghanaian drinking water treatment plants. The cyanobacteria composition and potential MCproducers differed among the sampled reservoirs. The most abundant species in the Owabi Reservoir was C. ferruginea, which has not been previously reported to produce MCs and little information on its ecology or toxicity exists (Addico et al., 2009). Since MCs were detected with high frequency in samples from the Owabi Reservoir, it might suggest this cyanobacterium could produce MCs. However, representatives of the above mentioned cyanobacterial genera associated with $\mathrm{MC}$ production, namely A. nygaardii, A. holsatica, Leptolyngbya sp. and $P$. recta were also present in the Owabi samples. Although concentrations of these species were much lower than $C$. ferruginea cell counts, their share of the total biomass might have been relatively larger due to the differences in their cell size. Since A. holstatica and P. recta (and also $C$. cronbergae) were detected along with $C$. ferruginea in the only Owabi sample of the treated water positive for MCs, it does not rule out these species as putative MC producers. In addition, MCs were detected much less frequently in the Barekese Reservoir, where C. ferruginea occurred in concentrations similar to Owabi. Other representatives of potentially MC-producing genera, such as A. nygaardii, Planktothrix sp., P. lacustris var. solitaria and P. recta were also present in the Barekese Reservoir, including the sample of treated water positive for intracellular MCs (February $10^{\text {th }}$ ). Thus, other species might have been responsible for MC production in the two reservoirs with abundant population of $C$. ferruginea, and experiments with the isolated strains are required to confirm picocyanobacterium $C$. ferruginea as a MC producer.

The highest encounted species in the Kpong Reservoir was G. unigranulatum. Cyanobacteria from Geitlerinema genus have been recently reported to produce MCs (Bernard et al., 2017; Myers et al., 2007; Valdor and Aboal 2007). However, other putative producers of MCs were also present in the Kpong reservoir, most notably $P$. agardhii, which also penetrated into the final stage of the water treatment on the sampling days when intracellular MCs were detected in the final water (March $10^{\text {th }}$, April $\left.8^{\text {th }}\right)$. The Weija Reservoir had a high diversity of cyanobacteria, including Anabaenopsis tanganyikae (G. S. West) Woloszynska \& V. V. Miller, $A$. nygaardii, $A$. nubilum, M. tenuissima, M. aeruginosa, $P$. agardhii or $P$. recta, which are not only species representing the genera potentially producing MCs (Bernard et al., 2017), but they were also detected in the final treated water containing intracellular MCs (February $9^{\text {th }}$ ).

Interestingly, the major cyanobacterial species in the Weija and Kpong Reservoirs changed from years $2002-$ 2003, when M. aeruginosa and D. flos-aquae were the most abundant, with their average concentrations in the water intake were around 10,000 cell $\mathrm{mL}^{-1}$ and corresponded to $41-51 \%$ of the total cyanobacterial cell counts (Addico et al., 2006). Addico et al. (2006) also observed breakthrough of cyanobacteria to the final treated water at the averaged total cell counts 685 cell $\mathrm{mL}^{-1}$, which is comparable to our current study. At that time, MCs were analyzed only in the water intake, where present at concentrations $0.03 \mu \mathrm{g} \mathrm{L}{ }^{-1}$ in the Kpong Reservoir and 3.21 $\mu \mathrm{g} \mathrm{L}^{-1}$ in the Weija Reservoir (Addico et al., 2006). In 2010, cyanobacteria and MCs were analyzed also in the Brimsu and Kwanyarko treatment plants in Ghana. $P$. agardhii, D. flos-aque and P. recta were the most abundant species in the water intake from the Brimsu Reservoir, whereas $M$. aeruginosa followed by $P$. agardhii and Merismopedia punctata MEYEN accounted nearly for $80 \%$ of the cyanobacterial cell counts in the raw water in the Kwanyarko treatment plant (Addico et al., 2017). Concentrations of cyanobacteria in the water intake were much lower (Brimsu: 2183 cell mL ${ }^{-1}$, Kwanyarko: 1286 cell $\mathrm{mL}^{-1}$ ) than in the current study or in the study of Addico et al. (2006), while concentrations of MCs in raw water were $0.79 \mu \mathrm{g} \mathrm{L}^{-1}$ in Brimsu and $0.10 \mu \mathrm{g} \mathrm{L}^{-1}$ in Kwanyarko. However, cyanobacteria (Brimsu: 103 cell $\mathrm{mL}^{-1}$, Kwanyarko: 85 cell $\left.\mathrm{mL}^{-1}\right)$ as well as MCs $(0.10 \mu \mathrm{g}$ $\mathrm{L}^{-1}$ in both plants) were detected also in the final water (Addico et al., 2017). 
These previously published findings together with the results presented in this paper demonstrate that MC-producing species and $\mathrm{MC}$ contamination are common and enduring health hazard in drinking water reservoirs in Ghana. Concentrations of cyanobacteria and MC have been shown to significantly decrease during the treatment process. Apparently, conventional drinking water treatment plants existing in Ghana were sufficiently effective in removing of MCs to the levels below the WHO limit for drinking water. However, samples of the final treated water often contained cyanobacterial cells. In addition to the most abundant species, i.e., C. ferruginea, G. unigranulatum and A. nubilum, other cyanobacterial species were observed to infiltrate the final water. These included most notably Planktothrix sp., C. raciborskii (Barekese, Kpong and Weija), P. recta (Barekese, Owabi), A. holstatica, Leptolyngbya sp. (Owabi), A. nygaardi (Barekese, Weija), $C$. cronbergae and M. aeruginosa (Weija), which were often found in the final water in disproportionately higher share than in the raw water. Correspondingly, intracellular or particle-associated MCs were found in the treated water, which indicates that the treatment process should be further optimized to remove cyanobacterial cells more effectively. This could include adjustments of the flocculant amount or application of a flocculant aid in response to changes in the raw water quality affecting coagulationflocculation-sedimentation process, such as turbidity, concentration of suspended solids and natural organic matter, phytoplankton abundance and composition (Hoeger et al., 2005; Merel et al., 2013; Westrick et al., 2010).

Our results also indicate that the stage with alum flocculation during the drinking water treatment yielded the higest intracellular MC concentrations. Samples from the flocculation stage were taken in the same manner as all the stations (water mixed with flocs). This might be due to large number of cells trapped in the flocs, as reported by Pietsch et al. (2002). Interestingly, the overall frequency of samples containing dissolved MCs also increased after the flocculation step (Barekese, Owabi, Weija) or pre-chlorination (Kpong). This is in agreement with previous observations that these treatment steps can lead to the damage of cyanobacterial cells due to sheer stress or chemical oxidation, resulting in the release of cyanotoxins into the surrounding water (Hoeger et al., 2005; Hrudey et al., 1999; Merel et al., 2013; Pietsch et al., 2002; Westrick et al., 2010).

Concentrations of dissolved MCs tended to decrease during the further steps of the water treatment, which might be attributed to their biodegradation during rapid sand filtration (Ho et al., 2006) or chlorination (Merel et al., 2010). However, the applied water treatment procedures in some instances actually resulted in the increase of dissolved $\mathrm{MC}$ concentrations even in the final treated water (Weija, January 24 ${ }^{\text {th }}$, and Kpong, March $24^{\text {th }}$ ), which indicates that the conventional treatment procedures are only partially effective for removal of dissolved toxins.

Among the four reservoirs studied, the Owabi Reservoir was the most contaminated reservoir in terms of both intracellular and dissolved MCs. As mentioned earlier in the methodology at the time of sampling the Owabi treatment plant, algaecide treatment with copper sulphate was simultaneously being done during water treatment and this may account for the higher level of samples containing dissolved $\mathrm{MCs}$ in this reservoir, putting consumers at higher risk of exposure to MCs. The dangers of using algaecides in drinking water reservoirs was demonstrated in an incident which occurred on tropical Palm Island, Australia, where members of the community became ill with hepato-enteritis following treatment of the water supply reservoir with copper sulphate after complaints of bad taste and odour from the population (Byth, 1980; Bourke et al., 1983). Jones and Orr (1994) suggested that if algaecides are used to control toxic cyanobacteria, the reservoir should be isolated for a period to allow the toxins and odour to degrade.

Although MC concentrations detected in samples of final treated water in our study were lower $(0.07-0.81 \mu \mathrm{g}$ $\mathrm{L}^{-1}$ ) than recommended WHO limit for MC-LR, Hoeger et al. (2005) cautioned that due to tumor promoting activities of MCs, chronic exposure of populations to concentration above $0.1 \mu \mathrm{g} \mathrm{L}^{-1}$ should be avoided. In fact, negative health outcomes have been associated with consumption of drinking water containing less than $1 \mu \mathrm{g} \mathrm{L}^{-1}$ of MCs, such as high incidence of primary liver cancer associated with the use of MC-contaminated water (maximal concentration $0.46 \mu \mathrm{g} \mathrm{L}^{-1}$ ) in Southern China (Ueno et al., 1996; Yu, 1989, 1995). However, it must be mentioned that other risk factors such as hepatitis B and exposure to aflatoxins from maize and other cereals were also implicated (Ueno et al., 1996). Chronic exposures to water contaminated with MCs at concentrations 1.1-3.28 $\mu \mathrm{g} \mathrm{L}^{-1}$ have been linked with the increased incidence of colorectal cancer (Zhou et al. 2002) or liver damage (Chen et al., 2009; Li et al., 2011) in China. In addition, there are reports on statistically significant associations between cyanobacterial blooms and non-alcoholic liver disease in USA (Zhang et al., 2015) or primary liver cancer in Serbia (Svircev et al., 2009, 2013, 2014).

The levels of MCs similar to those observed in this study have been linked also to acute effects (Wood, 2016). In Sweden, MCs at concentrations 0.1-0.5 $\mu \mathrm{g} \mathrm{L}^{-1}$ were detected in the drinking water during an acute non-fatal outbreak of gastroenteritis associated with mass development of MC-producing $P$. agardhii in the raw water supply (Annadotter et al., 2001). These reports indicate that negative health outcomes resulting from both acute and chronic exposure to drinking water contaminated with cyanobacteria might be associated with concentrations of MCs around $1 \mu \mathrm{g} \mathrm{L}^{-1}$ which might also interact with other factors, such 
as other bioactive substances from cyanobacteria (lipopolysaccharides and other cyanobacterial metabolites), pathogens or anthropogenic contaminants. More importantly, about $40 \%$ of people in Ghana overall and up to $80 \%$ in the rural areas does not have an access to the treated piped water (Kumasi et al., 2011; Stoler et al., 2012), and thus eventually relies on surface water and shallow wells without any treatment. This situation might pose much more serious human health risk, since according to our study, MCs occurred very frequently in the raw water, often at concentrations higher than WHO limit (27\% samples of intracellular toxins).

Massive proliferations of cyanobacteria are likely to continue during the next years due to the ongoing eutrophication and climate change (O'Neil et al., 2012). In combination with unsolved and increasing demands for safe drinking water in Ghana (Stoler et al., 2012), cyanotoxin occurrence in drinking water reservoirs in Ghana represents long-standing and probably intensifying issue, which needs to be adequately addressed by scientists, water treatment management and public health authorities.

\section{CONCLUSIONS}

Safe drinking water has been recognised as one of the most critical factors to guarantee long-term population health. Our study clearly demonstrated that the four studied treatment plants successfully met the WHO guideline value of $1 \mu \mathrm{g} \mathrm{L}^{-1}$. However, not only dissolved but also intracellular toxins and cyanobacterial cells were found in the final treated water, which indicates a borderline efficiency of the water treatment, possibly resulting in higher toxin concentrations if the treatment procedure gets compromised. In addition, populations drinking untreated surface water can be more often exposed to MC concentrations exceeding $1 \mu \mathrm{g} \mathrm{L}^{-1}$. The lessons to be learnt from this study are: i) The development of cyanobacterial blooms and $\mathrm{MC}$ contamination represent a serious health hazard all over the world and Ghana is no exception; ii) since there are neither cyanobacteria monitoring programs nor guidelines for $\mathrm{MC}$ concentration in drinking water in Ghana, it is recommended that all reservoirs used for drinking water production should be monitored regularly to optimize water treatment process and to protect the public health; iii) other cyanotoxins such as cylindrospermopsin or neurotoxins should be also considered in the further research, since their potential producers were detected in our study; iv) surface water resources should be protected through proper watershed management practices to reduce eutrophication and thus cyanobacteria blooms; v) mass education should also be undertaken to inform the public of the dangers of cyanobacteria and toxins and more importantly about their negative health effects on humans.

\section{ACKNOWLEDGMENTS}

The research was supported by the Government of Ghana. Microcystin analyses were also supported by a research project no. RVO 67985939, and by Czech Ministry of Education, Youth and Sports (projects no. LO1214 and LM2015051). We would also like to thank Professor Jiř́ Komárek (Institute of Botany, Czech Academy of Sciences, Trebon, Czech Republic) for the help with determination of cyanobacteria, Professor Linda Lawton and Dr. Christine Edwards (Robert Gordon University, Aberdeen, UK) for the help with microcystin analysis, Dr. Felix Akpabey and Ms. Doreen Ofosu (CSIR Water Research Institute, Accra, Ghana) for their assistance with sample collection and processing, Ralf Bubliz and Kerstin Hanisch (University of Hull, Hull, UK) for the help with HPLC analyses.

\section{REFERENCES}

Addico G, Hardege J, Komárek J, Babica P, de-GraftJohnson KAA, 2006. Cyanobacteria species identified in the Weija and Kpong reservoirs, Ghana, and their implications for drinking water quality with respect to microcystin. Afr. J. Marine Sci. 28:451-456.

Addico G, Hardege J, Komárek J, de-Graft-Johnson KAA, 2009. Cyanobacterial diversity and biomass in relation to nutrient regime of four freshwater reservoirs sourced for the production of drinking water in Ghana. Algol. Stud. 130:81-108.

Addico G, Lawton L, Edwards C, 2017. Hepatotoxic-microcystins in two drinking water reservoirs in the Central Region of Ghana. Toxicol. Forensic Med. 2:1-11.

Akin-Oriola GA, Anetekhai MA, Oriola A, 2006. Algal blooms in Nigerian waters: an overview. Afr. J. Marine Sci. 28:219-224.

Akoto O, Gyamfi O, Darko, G, Barnes VX, 2014. Changes in water quality in the Owabi water treatment plant in Ghana. Appl. Water Sci. doi:10.1007/s13201014-0232-4.

Amuzu AT, 1975. Water-treatment practices at Barekese water utility in Ghana. J. Am. Water Work. Assoc. 67:322-323.

Asante KA, Quarcoopome T, Amevenku FYK, 2008. Water quality of the Weija Reservoir after 28 years of impoundment. West African J. Appl. Ecol. 13:125-131.

Ansa-Asare DO, Asong-Asante K, 1998. Comparative study of the nutrient status of two reservoirs in Southeast Ghana. Lakes Reserv. Res. Manag. 3:205-217.

Annadotter H, Cronberg G, Lawton L, Hansson HB, Gothe U, Skulberg OM, 2001. An extensive outbreak of gastroenteritis associated with the toxic cyanobacterium Planktothrix agardhii (Oscillatorialis, 
Cyanophyceae) in Scania, South Sweden, p. 200-208. In: I. Chorus (ed.) Cyanotoxins - occurrence, causes, consequences. Springer-Verlag, Berlin.

Berger C, Ba N, Gugger M, Bouvy M, Rusconi F, Coute A, Troussellier M, Bernard C, 2006. Seasonal dynamics and toxicity of Cylindrospermopsis raciborskii in Lake Guiers (Senegal, West Africa). FEMS Microbiol Ecol. 57:355-366.

Bernard C, Ballot A, Thomazeau S, Maloufi S, Furey A, Mankiewicz-Boczek J, Pawlik-Skowronska B, Capelli C, Salmaso N, 2017. Appendix 2. Cyanobacteria associated with the production of cyanotoxins, p. 503527. In: J. Meriluoto, L. Spoof and G.A. Codd (eds.), Handbook on cyanobacterial monitoring and cyanotoxin analysis. J. Wiley \& Sons, Chichester.

Bláha L, Babica P, Maršálek B, 2009. Toxins produced in cyanobacteria water blooms. Interdisc. Toxicol. 2:36-41.

Bourke ATC, Hawes RB, Nelson A, Stallman ND, 1983. An outbreak of hepato-enteritis (the Palm Island mystery disease) possibly caused by algal intoxication. Toxicon 21:45-48.

Byth S, 1980. Palm Island mystery disease. Med. J. Aust. 2:40-42.

Chen J, Xie P, Li L, 2009. First identification of the hepatoxic microsystins in the serum of a chronically exposed human population together with indication of hepatocellular damage. Toxicol. Sci. 108:81-89.

Chia MA, Kwaghe MJ, 2015. Microcystins contamination of surface water supply sources in Zaria-Nigeria. Env. Monit. Assess. 187:606.

Chia MA, Abolude DS, Ladan Z, Akanbi O, Kalaboms A, 2009a. The presence of microcystins in aquatic ecosystems in Northern Nigeria: Zaria as a case study. Res. J. Environ. Toxicol. 3:170-178.

Chia MA, Oniye SJ, Ladan ZL, Pila AE, Inekwe VU, Mmerole JU, 2009b. A survey for the presence of $\mathrm{s}$ in aquaculture ponds in Zaria, Northern-Nigeria: Possible health implications. African J. Biotechnol. 8:6282-6289.

Fastner J, Flieger I, Neumann U, 1998. Optimised extraction of microcystins from field samples- a comparison of different solvents and procedures. Wat. Res. 32:3177-3181.

Feurstein D, Holst K, Fischer A, Dietrich DR, 2009. OATP-associated uptake and toxicity of microcystins in primary murine whole brain cells. Toxicol. Appl. Pharmacol. 234:3372-3378.

Feurstein D, Kleinteich K, Heussner AH, Stemmer K, Dietrich DR, 2010. Investigation of microcystin congener-dependednt uptake into primary murine neurons. Environ. Health Perspect. 118:1370-1375.

Fleming LE, Rivero C, Williams C, Bean JA, Shea KA, Stinn J, 2002. Blue green algal (cyanobacterial) toxins, surface drinking water, and liver cancer in Florida. Harmful Algae 1:157-168.
Grosse Y, Baan R, Kurt Straif K, Secretan B, El Ghissassi F, Cogliano V, 2006. Carcinogenicity of nitrate, nitrite and cyanobacterial peptide toxins. Lancet Oncol. 7:628-629.

Haande S, Ballot A, Rohrlack T, Fastner J, Wiedner C, Edvardsen B, 2007. Diversity of Microcystis aeruginosa isolates (Chroococcales, Cyanobacteria) from EastAfrican water bodies. Arch. Microbiol. 188:15-25.

Harding WR, Downing TG, Van Ginkel CE, Moolma PMA, 2009. An overview of cyanobacterial research and management in South Africa post-2000. Water SA. 35:479-484.

Harke MJ, Steffen MM, Gobler CJ, Otten TG, Wilhelm SW, Wood SA, Paerl HW, 2016. A review of the global ecology, genomics, and biogeography of the toxic cyanobacterium, Microcystis spp. Harmful Algae 54:4-20.

Harada K, Kondo F, Lawton L, 1999. Laboratory analysis of cyanotoxin, p. 369-399. In: I- Chorus and J. Bartram (eds.) Toxic cyanobacteria in water: A guide to their public health consequences, monitoring and management. E\&FN Spon, London.

Hoeger SJ, Hitzfeld B, Dietrich D, 2005. Occurrence and elimination of cyanobacterial toxins in drinking water treatment plants. Toxicol. Appl. Pharmacol. 203:231-242.

Ho L, Meyn T, Keegan A, Hoefel D, Saint CP, and Newcombe G, 2006. Bacterial degradation of microcystin toxins within a biologically active sand filter. Wat. Res. 40:768-774.

Hrudey S, Burch M, Drikas M, Gregory R, 1999. Remedial Measures, p. 275-312. In: I- Chorus and J. Bartram (eds.) Toxic cyanobacteria in water: A guide to their public health consequences, monitoring and management. E\&FN Spon, London.

Johansson S, Olsson M, 1998. Investigations of toxic algal blooms in algal blooms in a drinking water reservoir of Harare, Zimbabwe. MSc. Thesis, University of Lunds, Sweden.

Jones GJ, Orr PT, 1994. Release and degradation of microcystin following algicide treatment of a Microcystis aeruginosa bloom in a recreational lake, as determined by HPLC and protein phosphatase inhibition assay. Wat. Res. 28:871-876

Komárek J, Anagnostidis K, 1999. [Cyanoprokaryota. 1. Teil: Chroococcales], p. 1-548. In: H. Ettl, G. Gardner, H. Heynig and D. Mollenheuer (eds.), [Süsswasserflora von Mitteleurope].[Book in German]. Gustav Fischer Verlag.

Komárek J, Anagnostidis K, 2005. [Süßwasserflora von Mitteleuropa, Bd. 19/2: Cyanoprokaryota].[Book in German]. Springer Spektrum, Heidelberg: 759 pp.

Kumasi TC, Obiri-Danso K, Ephraim JH, 2011. Microbial quality of water in Barekese reservoir and feeder streams in Ghana. Lakes Reserv. Res. Manag. 16:49-60. 
Li Y, Chen JA, Zhao Q, Pu C, Qui Z, Zhang R, Shu W, 2011. A cross-sectional investigation of chronic exposure to microcystin in relationship to childhood liver damage in the three Gorges Resources Region, China, Environ. Health Perspect. 119:1483-1488.

Manganelli M, Scardala S, Stefanelli M, Palazzo F, Funari E, Vichi S, Buratti FM, Testai E, 2012. Emerging health issues of cyanobacterial blooms. Ann. Ist. Super. Sanità. 48:415-428.

McElhiney J, Lawton LA, 2005. Detection of the cyanobacterial hepatotoxins microcystins. Toxicol. Appl. Pharm. 203:219-230.

Merel S, Clement M, Thomas O, 2010. State of the art on cyanotoxins in water and their behaviour towards chlorine. Toxicon 55:677-691.

Merel S, Walker D, Chicana R, Snyder S, Baurés E, Thomas O, 2013. State of knowledge and concerns on cyanobacterial blooms and cyanotoxins. Environ. Int. 59:303-327.

Mhlanga L, Day J, Cronberg G, Chimbari M, Siziba N, Annadotter H, 2006. Cyanobacteria and cyanotoxins in the source water from Lake Chivero, Harare, Zimbabwe, and the presence of cyanotoxins in drinking water. Afr. J. Aquat. Sci. 31:165-173.

Mohamed ZA, Carmchael WW, 2000. Seasonal variation in microcystin levels of river Nile water at Sohag City, Egypt. Internat. J. Limnol. 36:227-234.

Mowe MAD, Mitrovix SM, Lim RP, Furey A, Yeo DCJ, 2014. Tropical cyanobacterial blooms: a review of prevalence, problem taxa, toxins and influencing environmental factors. J. Limnol. 74:1005.

Myers JL, Sekar R, Richardson LL, 2007. Molecular detection and ecological significance of the cyanobacterial genera Geitlerinema and Leptolyngbya in black band disease of corals. Appl. Environ. Microbiol. 73:5173-5182.

Nasri AB, Bouaicha N, Fastner J, 2004. First Report of a Microcystin-Containing Bloom of the Cyanobacteria Microcystis spp. in Lake Oubeira, Eastern Algeria. Arch Environ. Contam. Toxicol. 46:197-202.

Ndebele MR, Magadza CHD, 2006. The occurrence of microcystin-LR in Lake Chivero, Zimbabwe. Lakes Reserv. Manage. 11:57-62

Ndlela LL, Oberholster PJ, Van Wyk JH, Cheng PH, 2016. An overview of cyanobacterial bloom occurrences and research in Africa over the last decade. Harmful Algae 60:11-26.

Odokuma LO, Isirima JC, 2007. Distribution of cyanotoxins in aquatic environments in the Niger Delta. Afr. J. Biotechnol. 6:2375-2385.

O’Neil JM, Davis TW, Burford MA, Gobler CJ, 2012. The rise of harmful cyanobacteria blooms: the potential roles of eutrophication and climate change. Harmful Algae 14:313-334.
Pietsch J, Bornmann K, Schmidt W, 2002. Relevance of intra- and extracellular cyanotoxins for drinking water treatment. Actahydrochim. Hydrobiol. 30:7-15.

Quarcoopome T, Amevenku F, Ofori-Danson P, 2011. Changes in the fish community of the Kpong Headpond, lower Volta River, Ghana after 25 years of impoundment. Rev. Biol. Trop. 59:1685-1696.

Stoler J, Weeks J, Fink, G, 2012. Sachet drinking water in Ghana's Accra-Tema metropolitan area: past, present, and future. J. Water Sanit. Hyg. Dev. 2: 223-240.

Svircev Z, Krstic S, Miladinov-Mikov M, Baltic V, Vidovic M, 2009. Freshwater cyanobacterial blooms and primary liver cancer epidemiological studies in Serbia. J. Environ. Sci. Health C Environ. Carcinog. 27:36-55.

Svircev Z, Baltic V, Ganta M, Jukovic M, Stojanovic D, Baltic M, 2010. Molecular Aspects of Microcystin-induced Hepatotoxicity and Hepatocarcinogenesis. J. Environ. Sci. Heal. Part C-Environmental Carcinog. Ecotoxicol. Rev. 28:39-59.

Svircev Z, Drobac D, Tokodi N, Vidovic M, Simevnovic J, Mikov MM, Baltic V, 2013. Epidemiology of primary liver cancer in Serbia and possible connection with cyanobacterial blooms. J. Environ. Sci. Health C Environ. Carcinog. Ecotoxicol. Rev. 31:181-200.

Svircev Z, Drobac D, Tokodi N, Luzanin Z, Munjas ZL, Mikolin B, Vuleta D, Meriluoto J, 2014. Epidemiology of cancers in Serbia and possible connection with cyanobacterial blooms. J. Environ. Sci. Health C Environ. Carcinog. Ecotoxicol. Rev. 32:319-337.

Ueno Y, Nagata S, Tsutsumi T, Hasegawa A, Watanabe M, Park HD, Chen G, Yu SZ, 1996. Detection of microcystins, a blue-green algal hepatotoxin, in drinking water sampled in Haimen and Fusui, endemic areas of primary liver cancer in China, by highly sensitive immunoassay. Carcinogenesis 17:1317-1321.

United Nation Statistical Division, 2014. Demographic Yearbook. Available from: https://unstats.un.org/Unsd/ demographic/products/dyb/dyb2014.htm

Valdor R, Aboal M, 2007. Effects of living cyanobacteria, cyanobacterial extracts and pure microcystins on growth and ultrastructure of microalgae and bacteria. Toxicon 49:769-779.

Van Apeldoorn ME, Van Egmond HP, Speijers GJA, Bakker GJI, 2007. Toxins of cyanobacteria. Mol. Nutr. Food Res. 51:7-60.

Westrick JA, Szlag DC, Southwell BJ, Sinclair J, 2010. A review of cyanobacteria and cyanotoxins removal/inactivation in drinking water treatment. Anal. Bioanal. Chem. 397:1705-1714.

WHO, 1998. Guidelines for drinking water quality Cyanobacterial toxins: Microcystin-LR World Health Organisation, WHO, Geneva. 
Wood R, 2016. Acute animal and human poisonings from cyanotoxin exposure - A review of the literature. Environ. Int. 91:276-282.

Yu SZ, 1989. Drinking water and primary liver cancer, pp. 30-37. In: Z.Y. Tang, M.C. Wu and S.S. Xia (eds.) Primary liver cancer. Springer, Berlin.

Yu SZ, 1995. Primary prevention of hepatocellular carcinoma. J. Gastroenterol. Hepatol. 10:164-168.

Zhang F, Lee J, Liang S, Shum CK, 2015. Cyanobacteria blooms and non-alcoholic liver disease: evidence from a county level ecological study in the United States. Environ. Health 14:41.

Zhou L, Yu H, Chen K, 2002. Relationship between microcystin in drinking water and colorectal cancer. Biomed. Environ. Sci. 15:166-171.

Zilberg B, 1966. Gastroenteritis in Salisbury. European Children - a five year study. Cent. Afr. J. Med. 12: 164-168. 